\title{
下垂体・副腎摘出ラットの免疫能の変化
}

\author{
近田研・四方治 \\ 中嶋博久 久篠 崎隆 - 磯野倫夫 \\ 前野仁史・斎藤征夫・沢木偆二
}

Jpn. J. Clin. Immun., 8 (6): 389 392, 1985.

\section{Change of immunological function in hypophysectomized rats and adrenalectomized rats}

Kiwami Chikada, Osamu Shikata, Toru Otsuka, Hirohisa Nakajima, Takashi Shinozaki, Michio Isono,

Hitoshi Maeno, Yukio Saito and Shunzi Sawaki

The 1st Department of Internal Medicine, Aichi Medical University

\section{【Summary】}

The primary role of the thymus in immunological function is unanimously recognized. It is also proposed that hypothalamus, hypophysis and adrenal system may be acting as a factor to control immunological activity, but the detail mechanism of this system remains inclarified.

We have reported that serum immunogloblin levels in hypophysectomized rats and adrenalectomized rats have elevated.

We analysed surface cell markers (W 3/13, W $3 / 25$ and ox 8 ) of lymphoid tissue cells (thymus, spleen and peripheral blood lymphocytes) in rats either hypophysectomized or adrenalectomized using by FACS 440 . Ox $8^{+}$peripheral blood lymphocytes decreased and W $3 / 25^{+} / 0 \times 8^{+}$ratio of spleen lymphocytes and peripheral blood lymphocytes elevated in hypophysectomized and adrenalectomized rats.

These results suggest that hypophysis and adrenal axis have the potential to regulate immunological system.

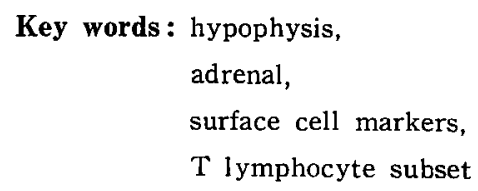

【概 要】

免疫機能における胸腺の中枢的な役割はよく認識されている，視床下部・下垂体・副腎系も免疫反応をコントロー ルする 1 因子と考えられているが，その詳細は不明である. 著者らは以前, 下垂体摘出・副腎摘出ラットにおいて， 
血清免疫グロブリン量の増加することを報告した．今回，下垂体摘出・副腎摘出ラットのリンパ系細胞（胸腺・脾㺃・ 末梢リンパ球) の表面マーカー (W 3/13・W 3/25・ox 8) を，FACS 440 を用いて解析した。 下垂体摘出・副腎摘出 ラットの末梢リンパ球・ox $8^{+}$細胞の減少と, 脾細胞・末梢リンパ球の $\mathrm{W} 3 / 25^{+} / \mathrm{ox} 8^{+}$比の上昇を認めた. これらの 結果より，下垂体・副腎は免疫機構の調節に関与していると思われる.

\section{I. 緒 言}

Baroni ${ }^{1)}$, Pierpaoli ${ }^{2)}$ らが下垂体前葉の欠損している Snell pituitary dwalf mouse における胸腺の萎縮を報 告して以来, 下垂体は副腎とともに免疫との関保に扮い ても研究されている. 著者らも以前より下垂体・副腎系 の免疫一の影響に注目し, 下垂体摘出・副腎摘出ラット で免疫グロブリン量が増加することなどを報告しだ， 今回, 下垂体・副腎が免疫グロブリン量をはじめ免疫系 にいかなる影響を与えているかを明らかにするために, 下垂体摘出・副腎摘出ラットの胸腺・脾臓・末梢リンパ 球の表面マーカー $\left(W 3 / 13 \cdot W 3 / 25 \cdot 0 \times 8^{4,5)}\right)$ FACS 440 を用いて解析し，興味ある結果を得たので報告する.

\section{II. 実験材料および方法}

(1) Sp. Dawly rat (早) を用い, 生後 3 週齢にて下垂 体摘出 $(10$ 匹) ·副腎摘出 $(10$ 匹) を行い, 摘出後 21 日 から 28 日の間に実験を行った，なお control として無 処置・同週秢のものを用いた.

（2）リンパ采細胞浮遊液：胸腺は細切後メッシュ通過 させ使用. 脾葴は細切・メッシ二通過後, 比重分離にて リンパ球層をとりだした. 末梢リンパ球（以下 PBL と
略す)は比重分離法でとりだした．各細胞浮遊液は 2 回 洗浄後 $5 \times 10^{6}$ 個/m $l$ (in RPMI-1640 addition $1 \%$ FBS) に調整。

(3) 単クローン抗体 : Sera-lab. Ltd の W3/13 (T. cell $\cdot$ thymocyte) $\cdot \mathrm{W} 3 / 25$ (helper $T$-cell) $\cdot$ ox 8 (nonhelper T-cell)を $20 \mu l / \mathrm{m} l$ に希勫し用いた ${ }^{4,5)}$.

(4) FITC 標識抗マウス IgG [ヤギ, F ( $\left.\left(a^{\prime}\right)_{2}\right]$ 血清 (Cappel)を $200 \mu l / \mathrm{m} l$ に希䣋し用いた.

（5）各種表面マーカーの検索は，(2) の細胞浮遊夜 500 $\mu l$ に(3)の抗体 $50 \mu l$ を加え $4^{\circ} \mathrm{C} 1$ 時間反応させ, 2 回 洗浄後 (4)の FITC $100 \mu l$ を加え再び $4^{\circ} \mathrm{C} 1$ 時間反応. 2 回洗浄後 FACS 440 にて測定した.

\section{III. 結 果}

Fig. 1 は下垂体摘出 (以下 H.E. と略す)・副腎摘出 (以下 A.E. と略す) ラットと control の W $3 / 13 \cdot W 3 /$ 25 の陽性率である. T-cell と thymocyte のマーカーで ある W $3 / 13$ 陽性率は, control の脾細胞平均 $49.8 \%$ 。 PBL 平均 72.1\%に対し A.E. ラットはそれぞれ平均 $42.8 \%$ 平均 $63.0 \%$ と低値を示した. helper T-cell の マーカーである W $3 / 25$ 陽性率は, 両者とも大きな変化 を認めなかった。

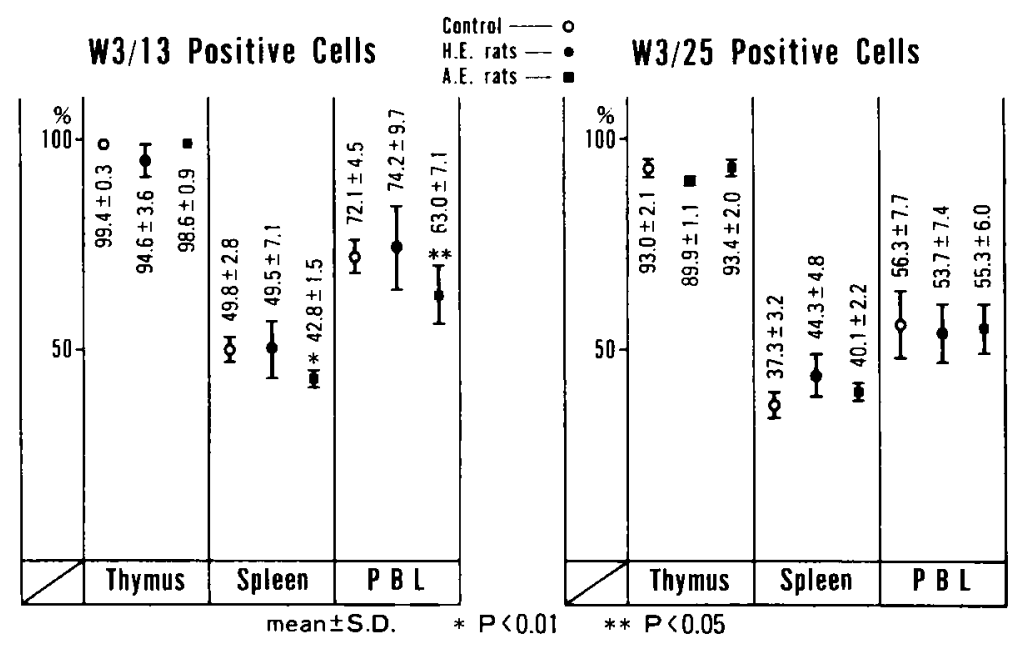

Fig. 1 Surface cell markers (W3/13, W3/25) of lymphoid tissue cells (thymus, spleen and peripheral lymphocytes) in hypophysectomized (H.E.) rats and adrenalectomized (A.E.) rats 


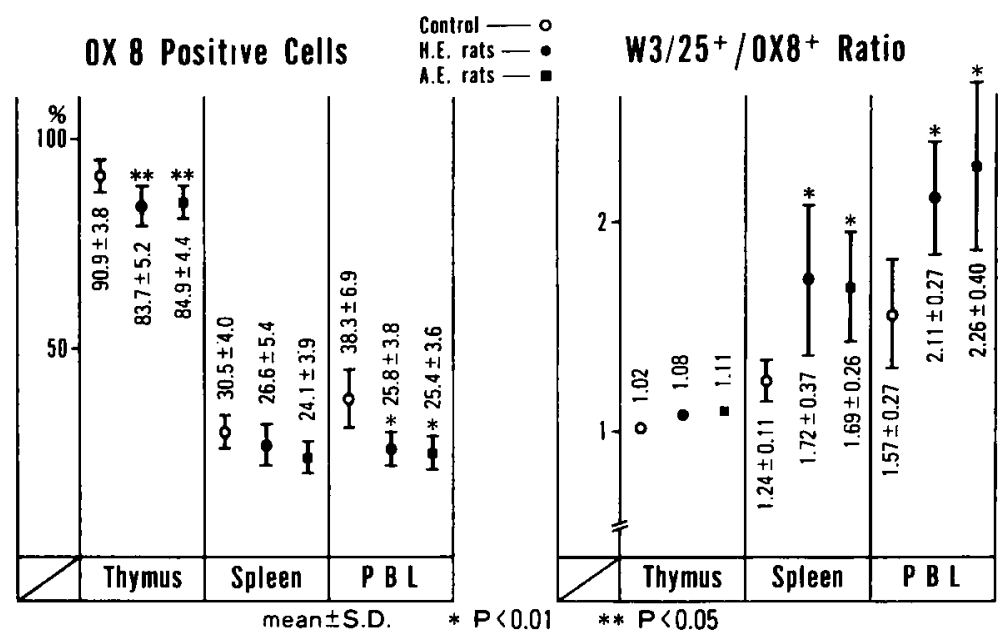

Fig. 2 Surface cell markers (ox 8 ) and $\mathrm{W} 3 / 25^{+} / \mathrm{OX} 8^{+}$ratio of lymphoid tissue cells (thymus, spleen and peripheral lymphocytes) in hypophysectomized (H.E.) rats and adrenalectomized (A.E.) rats

Fig. 2 は non-helper T.cell のマーカーで suppressor 活性をもつといわれている $0 \times 8$ 陽性率とW $3 / 25^{+} / 0 \times 8^{+}$ ratio である.ox 8 陽性率は胸腺で control 平均 $90.9 \%$ に対し H.E. ラット平均 83.7\% A A.E. ラット平均 84.9 \%と両者とも低值を示し, PBL でも control 平均 $38.3 \%$ に対し H.E. ラット平均 $25.8 \%$ A.E. ラット平均 25.4 $\%$ と両者とも著明な低值を示した. W 3/25+/ox $8^{+}$ratio は，脾細胞において control 平均 1.24 に対し H.E. ラッ 卜平均 1.72 - A.E. ラット平均 1.69 と両者とも上昇し, PBL の ratio \& control 平均 1.57 に対し, H.E.ラット 平均 2.11 -A.E. ラット平均 2.26 と両者で上昇を示し た. W 3/25 陽性細胞は helper 活性を, ox 8 陽性細胞は non-helper 活性 (suppressor 活性を含を) をむつため， H.E. ラット・A.E. ラットとも相対的に suppressor 活 性が低下していることが示唆された。

\section{IV. 考案}

下垂体と免疫との関俰は，Baroni ${ }^{1)} \cdot$ Pierpaoli $^{2)}$ らの Snell pituitary dwarf mouse での免疫能の低下の報告 以来注目されている.Pierpaoli6) らは，ヌードマウスに おける胸腺移植実験での免疫反応の回復には, 下垂体が 正常に営まれていることが必要と報告している．また， Cosma ら $ら^{7}$ は, 皮虏移植の拒絶反応の促進に GH と ACTH が関与していると報告している.このように,下 垂体ホルモン, とくに GH・ACTH の免疫への影響は数 多く報告されている8 10).

著者らは，下垂体摘出・副腎摘出ラットでの血清免疫
グロブリン量 $(\mathrm{IgG} \cdot \mathrm{IgM})$ の増加することを以前報告 した.この機序を解明するため，今回リンパ系細胞の表 面マーカーを検索したところ，下垂体摘出ラット・副腎 摘出ラットとも T cell の suppressor 活性の低下を示 唆する所見を得た. 副腎摘出ラットにおいて, 下垂体摘 出ラットと同様の変化を認めたことは, GH・ACTH の 影響といらよりは、コルチコイド系の影響がこれらの変 化を起こしていると考えられる. MoreI ら ${ }^{11)}$ は，下垂体 摘出・副篮摘出ラットでの胸腺細胞の分泌活性に括い て, 下垂体摘出での活性の低下は GH と ACTH 両者の 投与で回復し，副腎摘出ラットに ACTH を投与すると 活性が大きく低下することを報告している，つまり， $\mathrm{ACTH}$ の刺激効果は，副堅皮質からのコルチコイドの分 泌え進によることを示唆したものである．著者らの実験 でも，これを示唆するデータが得られた。

下垂体が胸腺の免疫学的機能を促進するのは, 主とし て GH であると考えられているが, ACTH-コルチコイ ド系の影響む重要な役割をはたしていると思われる、し かし，著者らの実験では，コントロールに sham-operated rat を用いていないため，全身状態の悪化など二次 的変化の影響は否定できない，さらに詳細な検索が必要 である。

\section{V. 結 語}

（1）下垂体摘出·副腎摘出ラットのリンパ系細胞の各 種表面マーカーを検索し，両者の末梢リンパ球で suppressor T cell 活性を有する ox 8 陽性細胞の低下を認 
めた.

（2） Helper T cell 活性を有する W 3/25 陽性細胞と

文献

1) Baroni, C. : Mouse thymus in hereditary pituitary dwarfism. Acta. anat., $68: 361 \sim 373,1967$.

2) Pierpaoli, W., Sorkin, E. : Relationship between thymus and hypophysis. Nature., 215 : 834 837, 1967.

3) 斎藤征夫 ·近田 研 - 他 7 名 :下垂体・副腎の免 疫に与える影響. 日臨免会誌, $5: 200 \sim 203,1982$.

4) Brideau, R.J., Carter, P.B. et al. : Two subsets of rat $\mathrm{T}$ Iymphocytes defined with monoclonal antibodies. Eur. J. Immunol., $10: 609 \sim 615$, 1980.

5) Williamus, A.F., Galfrè, G. et al. : Analysis of cell surfaces by xenogenic myeloma-hybrid antibodies : Differentiation antigen of rat lymphocytes. Cell., $12: 663 \sim 673,1977$.

6) Pierpaoli, W., Kopp, H.G. et al. : Interdependence of thymic and neuroendocrine functions in ontogeny. Clin. Exptl. Immunol., 24 : 501 506, ox 8 陽性細胞との比, W 3/25 $/$ ox $8^{+}$ratio 西両者の脾細 胞・末梢りンパ球で上昇を示した.

1976.

7) Cosma, J., Leonhardt, H. et al. : Influence of the thymus-corticotropin-growth hormone interaction on the rejection of skin allografts in the rat. Ann. N.Y. Acad. Sci., 249 : 387 401, 1975.

8) Berczi, I., Nagy, E. et al.: Reguration of humoral immunity in rats by pituitary hormones. Acta. Endocrinol., $98: 506 \sim 513,1981$.

9) Guseinov, S.G., Aliev. M.G. et al. : Effects of corticotropin on the thymus and the hypothalamo-pituitary-adrenal system. Neurosci. Behav. Physiol., 13 : 135 138, 1983.

10) Baroni, C.D., Fabris, N. et al. : Effects of hormones on development and function of lymphoid tissues. Immunology., $17: 303 \sim 314,1969$.

11) Morel, G., Deschaux, P. et al. : Caryometric study of thymic reticular cells in the rat. Experientia., 33 : 544 545, 1977. 